Zoologica Poloniae (2012) 57/1-4: 21-46

DOI: $10.2478 / \mathrm{v} 10049-012-0002-5$

\title{
HYDROALCOHOLIC EXTRACTS OF ECLIPTA ALBA AS A REVERSAL AGENT IN BORIC ACID INDUCED MALE REPRODUCTIVE TOXICITY
}

\author{
POOJA NAIR, Nidhi Vora, KaVERi Purandhar, \\ Vishal Kamle and SRIRAM SEShadri*
}

Institute of Science, Nirma University, Sarkhej Gandhinagar Highway, Village - Chharodi Ahmedabad, Gujarat - 382481, sriram.seshadri@nirmauni.ac.in, sriramsjpr@gmail.com, sriramsjpr@rediffmail.com

\begin{abstract}
Boric acid administration has a detrimental effect on reproductive organs, livers, and kidneys in rats. In the present study, male Wistar rats were orally fed with boric acid at a dose regimen of $350 \mathrm{mg} / \mathrm{kg}$ bodyweight for a period of 30 days, followed by oral administration of hydroalcoholic extract of Eclipta alba at a dose regimen of $500 \mathrm{mg} / \mathrm{kg}$ body weight orally for 60 days. The boric acid treated group showed signs of toxicity, such as liver damage, nephropathy, and complete damage to the testis, as early as 15 days which became aggravated by 30 days of the boric acid study period. Oxidative stress in all of the vital organs showed a significant increase. Following the plant extract treatment, complete reversal in reproductive toxicity was observed. The hormonal levels viz., testosterone, estrogen, and FSH returned to normal ranges after the 60 days of plant extract treatment. Significant reversal comparable to the control groups was observed in oxidative stress in the vital tissues. The fertility of the rats was found to be restored. The altered tissue morphology showed significant signs or recovery as observed under light microscopic examination. Thus, overall recovery was observed in the boric acid treated rats which received treatment with the plant extract. It can be concluded that Boric acid definitely has detrimental effects on the male reproductive system and the plant extract showed promising results. However, the mode of action and the active components for the same needs to be further investigated.
\end{abstract}

Key words: boric acid, reproductive toxicity, Eclipta alba, testis, testosterone, semen parameters 


\section{INTRODUCTION}

Reproductive toxicity includes adverse effects on sexual function and fertility in adult males and females as well as developmental toxicity in the offspring. The major manifestation of developmental toxicity includes death of the developing organism, structural abnormality, altered growth, and functional deficiency (www.ilo.org/legacy/english/protection/safework/ghs/.../ghsc11.pdf).

Boric acid generally is of moderate acute toxicity, and has been placed in Toxicity Category III for most acute effects, including oral and dermal toxicity, and eye and skin irritation. Most poisonings by boric acid have occurred in connection with its former use as a local antiseptic applied to irritated skin, burns, or wounds (FISHEL 2005). Within commercial products and the most important minerals that contain boron are borax pentahydrate, sodium perborate, boric acid, colemanite, and ulexite. Different applications for these compounds exist, notably: fiber glass, enamels, fire delayers, fertilizers, and agricultural herbicides (IPCS 1998).

The target cell for boric acid is elongated spermatid which leads to retention and phagocytosis of step 19 spermatid and abnormalities in released sperm. Failure of spermiation, where the mature testicular sperm fails to be released into the lumen and is instead phagocytized by the Sertoli cell is frequently seen upon administration of boric acid. This reflects a disturbance in the function of the Sertoli cell (CREASY et al. 2001). Inhibition of spermiation is due to functional changes in the physiology of Sertoli cells. The Sertoli cell is thought to be the target for boric acid toxicity (FUKUDA et al. 2000).

High-dose boric acid (BA) exposure produces testicular lesions in adult rats characterized by inhibited spermiation (IS) that may progress to atrophy. Significant decreases in serum inorganic phosphorus and creatinine were observed that worsened with dose and time of boric acid exposure. Boric acid affects the DNA synthetic activity of mitotic and meiotic germ cells by interfering with the production and/or maturation of early germ cells, thus promoting the testicular atrophy seen in boric acid-exposed rats ( $\mathrm{Ku}$ et al. 1993). The mechanism for the apparent selective testicular toxicity of boric acid remains obscure, and has not been thoroughly studied. One mechanism could be decreased testosterone.

Although research has been carried out with different synthetic compounds for cancer treatment, only limited success has been achieved. The conventional medicinal system provides a valuable tool for therapeutic research. Ayurvedic plants and their components mediate their effects by modulating several recently identified therapeutic targets. Environmental compounds are known to be involved in both the generation and reversal of toxicity. It is important to discover naturally occurring compounds which can block the toxicity or reverse it.

Extracts of Hibuscus sabdariffa (roselle) and Zingiber officinale (ginger) reduced the extent of cisplatin-induced sperm abnormality and enhanced sperm motility. Both extracts restored the control level of malondialdehyde (MDA) 
(lipid peroxidation marker) in the cisplatin-treated testis. Cisplatin injection induced decline in the levels of superoxide dismutase (SOD), reduced glutathione (GSH) and catalase (CAT) were significantly reversed to control levels in groups where cisplatin was preceded by the administration of either H. sabdariffa or Z. officinale. Thus, both H. sabdariffa and Z. officinale treatment increased the activities of testicular antioxidant enzymes and restored sperm motility of cisplatin-treated rats (Amin and Hamza 2006).

In the present investigation, the hydroalcoholic extract of the leaves of Eclipta alba was used to determine its reproductive toxicity reversal potential. $E$. alba has been reported to possess a diverse therapeutic usage such as hepatoprotective activity (CHAUDHARY et al. 2011), antinociceptive activity, antiinflammatory, and bronchodilator activity; analgesic activity; immunomodulatory activity, antiviral activity, antioxidant activity and antihyperglycemic activity, wound healing activity, and antifungal activity (Тноват et al. 2010).

\section{MATERIAL \& METHODS}

\section{Experimental Animals}

Thirty-three Healthy adult male Wistar rats, weighing 150-250 g were procured from Zydus Research Centre, Ahmedabad, complying with CPSCEA guidelines. The protocol for the present investigation (project no. IS/BIOCHEM// MSC11-12/1016) was approved by the Institutional Animal Ethical Committee (IAEC). The Guidance for Care and Use of Animals for Scientific Research (Indian National Science Academy, 2000) was strictly followed. The animals were acclimatized for two months under controlled conditions of temperature $\left(22 \pm 1^{\circ} \mathrm{C}\right)$, humidity $(60 \pm 5 \%)$, and light ( $12 \mathrm{~h}$ light: $12 \mathrm{~h}$ dark cycle), prior to the experiments. The animals were monitored every day for their body weight, food and water intake, and any visible symptoms, during the whole experiment.

\section{Plant Extract}

Dry powder of Eclipta alba leaves was obtained from LVG (Ayurvedic product supplier), Ahmedabad and was authenticated by Dr. Vasant A. Patel, Department of Botany, Smt. S.M.P. Science College, Hemachandracharya North Gujarat University, Gujarat, India. Specimen sample of E. alba has been submitted at the Institute of Science, Nirma University, Ahmedabad, Gujarat, India with the voucher no. ISNU/EA/CN-120422/01.

Eclipta alba extract (EAE) was prepared by suspending dry leaf powder in $50 \%$ ethanol in ratio of $1: 3$ and stirring it overnight at $50^{\circ} \mathrm{C}$, followed by filtration under sterile conditions. The filtrate was vacuum dried at $50^{\circ} \mathrm{C}$ to remove the solvent completely, weighed and reconstituted in distilled water to make $50 \mathrm{mg} / \mathrm{ml}$ extract (ChAUdhary et al. 2011).

\section{Chemicals}

Boric acid was procured from Merck KGaA, Ahmedabad. All other chemicals were of analytical grade. 


\section{Dosage}

Boric acid (350mg/kg bodyweight) was dissolved in distilled water and administered orally on a daily basis for 30 days to 24 animals. 18 animals from the boric acid treated group following 30 days of treatment were subjected to EAE administration, on a daily basis for 60 days at a dose regimen of $500 \mathrm{mg}$ / $\mathrm{kg}$ body weight, as determined as the effective dose in other studies carried out in our laboratory (CHAUdHARY et al. 2011).

\section{Treatment Schedule}

The animals were divided into three groups comprising 9 animals in the control group, 24 in the boric acid treated group, and 19 in the reversal group (Table 1).

Table 1: Treatment Groups

\begin{tabular}{clc}
\hline $\begin{array}{c}\text { Group } \\
\text { No. }\end{array}$ & \multicolumn{1}{c}{ Treatment Group } & $\begin{array}{c}\text { Number of } \\
\text { Animals }\end{array}$ \\
\hline 1. & Control Group & 9 \\
2 (a) & $\begin{array}{l}\text { Boric Acid induced Toxicity group @ 350mg/kg bodyweight/day/rat } \\
\text { for 30 days }\end{array}$ & 24 \\
2 (b) & $\begin{array}{l}\text { EAE treated group following Boric acid induced toxicity @ } 500 \mathrm{mg} / \mathrm{kg} \\
\text { body weight/day/rat for 60 days }\end{array}$ & 18 \\
\hline
\end{tabular}

\section{Parameters}

Diet and water intake were monitored on a daily basis throughout the study duration. Changes in external morphology and hair loss were also observed and monitored. The body weight of all the animals was recorded on a daily basis. The tissue weights of testis, liver and, kidney were recorded at the time of necropsy.

\section{Necropsy Schedule}

Three animals of each group were sacrificed to study the reproductive physiology by performing necropsies. Three animals from each group were sacrificed at regular intervals of 15 days using a high concentration of anesthesia. Dissected reproductive organs were used for histological evaluation and tissue biochemistry. Semen was collected from epididymis for basic semen analysis (WHO 2010) and the collected blood was used for blood profiling and serum biochemical analysis.

\section{Tissue Processing}

\section{Histological Studies}

For histological studies, the testis, liver, and kidneys were removed at the time of necropsy, cleared of all fat tissues and fixed in Bouin's fixative, and dehydrated and embedded in paraffin for sectioning at $5 \mu \mathrm{m}$. These sections were stained with Harris hematoxylin and eosin. 


\section{Tissue Biochemistry}

Testis, liver, and kidney were homogenized and frozen at $-20{ }^{\circ} \mathrm{c}$ for tissue biochemical assays. At the time of use, the homogenates were thawed and used for the analysis of cholesterol (Zlatkis et al. 1953, King and Wootton 1956) and protein (Lowry et al. 1951).

\section{Antioxidant Assays}

To determine the oxidative stress in the present investigation, Malondialdehyde (MDA) (Mihara and Uchiyama 1978) and Reduced Glutathione (GSH) (Beutler et al. 1963) activities were analyzed for all of the study groups.

\section{Semen Sample Collection}

Following necropsy, sperm were isolated separately from each of the epididymis by gently shearing the tissues and rupturing the tubules, allowing sperm to float into the medium $(0.9 \% \mathrm{~N}$-Saline) (Kempinas and Lamano-Carvalho 1988). The seminal fluid with the sperm suspended in N. saline was used for semenological and semen biochemical assessment.

\section{Preparation of Semen Sample}

Sperm were separated from seminal plasma by centrifugation and subjected to various tissue biochemical assays. If tests of sperm function are to be performed, it is critical that the spermatozoa are separated from seminal plasma within $1 \mathrm{hr}$ of collection, to limit any damage from products of non-sperm cells.

\section{Semenology}

During semen evaluation, the following parameters were considered. The semen sample was analyzed for its count, motility, viability, and morphology. Semenology was performed as per guidelines of the WHO manual (2010).

\section{Sperm Functional Tests}

\section{Hypo-osmotic swelling}

As an alternative to dye exclusion, the hypo-osmotic swelling (HOS) test was used to assess vitality (JEYENDRAN et al. 1984). The number of unswollen (dead) and swollen (vital) cells were determined with the aid of a laboratory counter.

\section{Semen Biochemistry}

Secretions from the accessory glands were measured to assess gland function. The following organelle markers were assayed, LDH (www.workington-biochem.com/ $\mathrm{LDH} /$ default.html) and testosterone for testicular function by ELISA, $\alpha$-glucosidase for Seminal Vesicle functioning, L-Carnitine, and glycerophosphocholine (GPC) as epididymal markers and citric acid and acid phosphatase (GAVella 1988) to ascertain the prostate functioning. 


\section{Blood Collection}

Blood was collected through heart puncture at the time of necropsy in EDTA coated tubes. The blood samples were collected in two different tubes. One tube had anticoagulant for the blood count while the second tube was without anticoagulant for serum analysis and haematocrit parameters respectively. The tube without the anticoagulant was kept in ice box and the supernatant was subjected to centrifugation for serum separation.

\section{Blood Profiling}

Hematology of the blood samples was carried out in order to detect the variation in the RBC and the WBC counts. Total white blood corpuscles (WBC), total red blood corpuscles (RBC), and platelet counts were made by using an improved Neubauer's haemocytometer (Lynch et al. 1969). The haematocrit values, haemoglobin, packed cell volumes (PCV), mean corpuscular volume MCV), mean corpuscular hemoglobin $(\mathrm{MCH})$, and mean corpuscular hemoglobin concentration (MCHC) were recorded according to NATELSON (1951) and LYNCH et al. 1969).

\section{Serum Biochemistry}

The serum separated following the blood collection was used for serum biochemical assays. The following parameters were estimated using reagent kits: total protein, glucose, cholesterol, creatinine, serum glutamate pyruvate transaminase (SGPT), bilirubin, urea, serum glutamate oxalate transaminase (SGOT), creatinine kinase (CK), triglycerides (TGL), and high density lipoproteins-cholesterol (HDL).

\section{Hormone Analysis}

The serum samples were also used for hormonal analysis of testosterone, estrogen, and FSH levels using ELISA based kits.

\section{Statistical Analysis}

Results are presented as mean \pm SD for three animals. A statistical difference between the means of the various groups was analyzed using one way analysis of variance (ANOVA). The statistical significance was evaluated by t-test. The boric acid treated group was compared with the control while the plant extract treated group was compared with the boric acid treated group.

\section{RESULTS}

There was no significant trend observed with respect to the daily food and water intake, but there was an increased intake of food as well as water in boric acid treated animals, as compared to the control and plant extract treated group.

The general observation in boric acid treated group was that these animals showed hair loss and had a drop in their body weight which was not observed in other groups (Data not shown). 


\section{Histological Studies}

Testis

The micrographs of testis in vehicle treated control animals reveals normal arrangement of the internal structure of the seminiferous tubules (indicated by thick arrow). The tubules were observed to be connected through interstitial space containing endocrine cells and Leydig cells (indicated by thin arrow). Sperm accumulation was observed in the seminiferous tubules (Figure 1a).
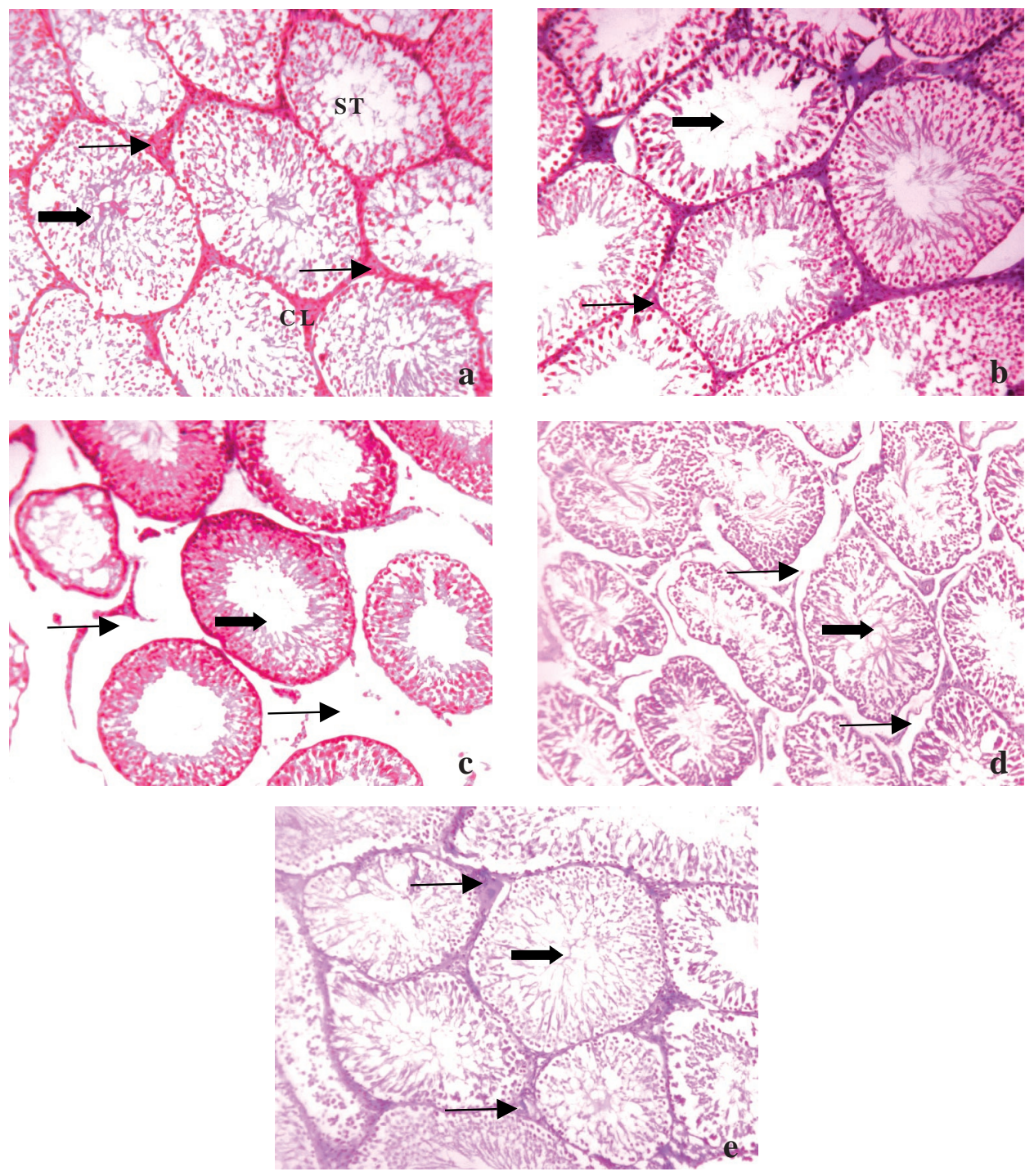

Figure 1 a-e: Histological section of testis of Control, Boric Acid, and Plant Extract treatment groups. Thick arrows indicate seminiferous tubules and thin arrow indicated Leydig cells. 
Following 15 days of boric acid treatment, the histological studies revealed gradual degradation of the seminiferous tubules and complete degeneration of the interstitial space was observed i.e., leydig cells were almost absent following 30 days of boric acid treatment. The internal arrangement of the seminiferous tubules was also observed to be completely distorted. The lumen of seminiferous tubule was completely devoid of any sperm accumulation (Figure 1b-c).

Re-appearance of the connecting tissue was observed in testis after the completion of 30 days of plant extract treatment indicating restoration of the Leydig cells (LC). The internal arrangement of the seminiferous tubules (ST) was also observed comparable to that of the control group. A gradual restoration of the testis function was observed in animals following 60 days of plant extract treatment. The interstitial space was observed to redevelop at a steady rate. Sperm accumulation was observed to initiate after 60 days of PE treatment indicating a speedy recovery (Figure 1d-e).

\section{Liver}

The micrographs of livers of vehicle treated control animals revealed that the liver lobule contains a number of hepatic acini and each centered on a portal tract. The tissue also contains sparse collagenous tissue acting as a cushion for development and functioning of the acini. The hepatic venules were also observed on the terminal of the heptocytes. The spacing between the hepatic cells was observed to be regular (Figure 2a).

The arrangement of the hepatocytes in 15 and 30 days boric acid treated animals was found to increase compared to that of the vehicle treated control animals. The collagenous tissue was completely absent in the tissue. The hepatic venule was observed to be enlarged while the portal tract was also observed to be damaged (Figure $2 b-c$ ). The damage to the liver was also associated with the infiltration of blood cells indicative of inflammatory activity which was noted throughout the section (Indicated by arrow).

After 30 days of plant extract treatment, the collagenous tissue was observed to reappear. Healing in the portal tract was also observed. The spacing between hepatic cells was observed to reduce compared to that of the boric acid treated group, but the arrangement was still irregular (Figure 2d).

A gradual re-development of the hepatic tissue was observed following the 60 days of PE extract treatment. The spacing between the hepatocytes was observed to condense compared to that of the boric acid treated group animals, almost comparable to that of the control. The collagenous tissue was observed to re-appear in the tissue in a stepwise manner. The hepatic venules were also observed that were comparable to that of the vehicle treated control animals. Although, the histoarchitecture of the liver recovered back to normalcy, there were still occurrence of blood cell accumulation but these accumulations were significantly reduced compared to the boric acid treated group, indicating that the extract also possess anti-inflammatory potentials which need to be ascertained in the future (Figure 2e-f). 

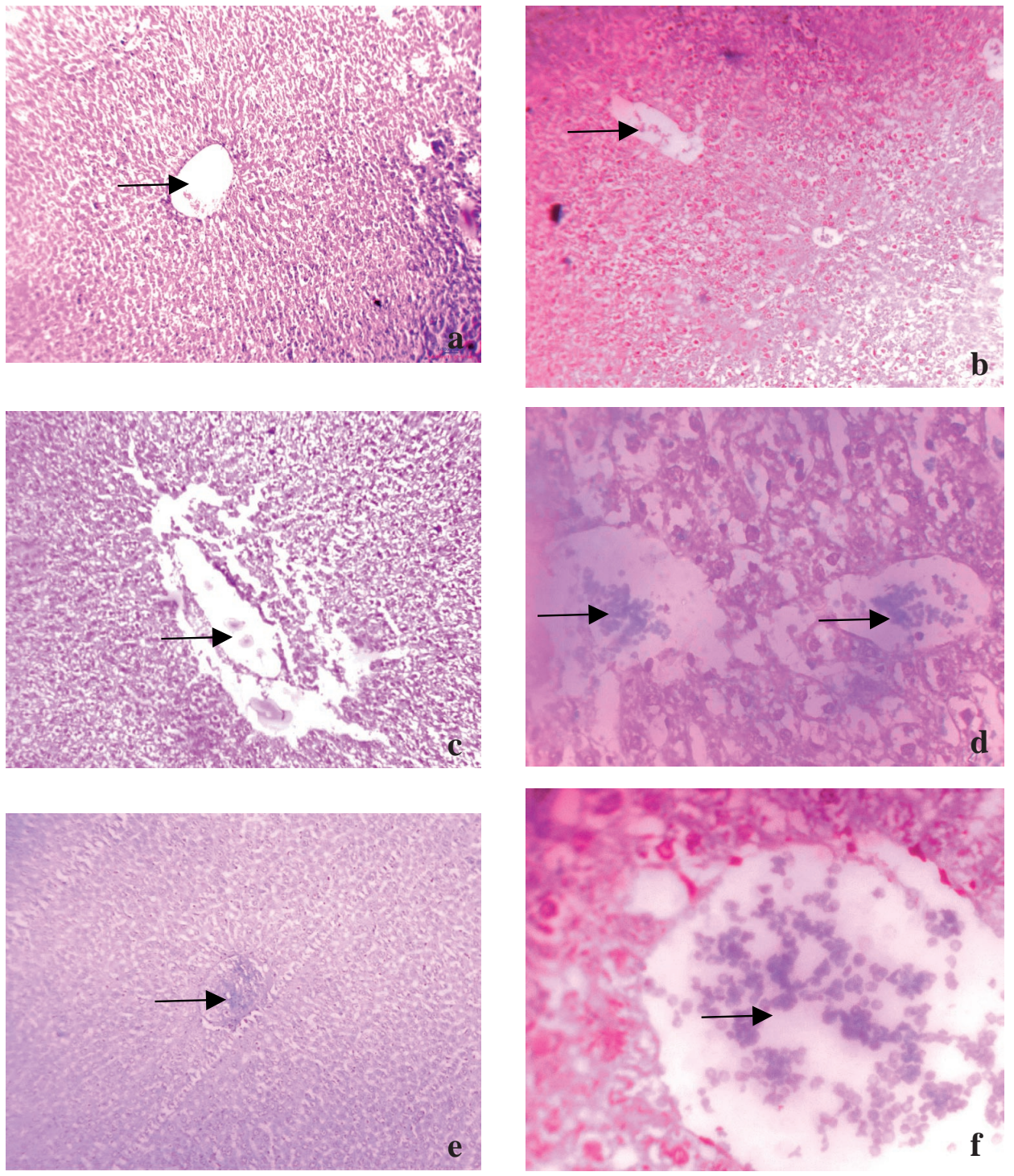

Figure 2a-f: Histological section of Liver of Control, Boric Acid, and Plant Extract treatment groups. Thin arrow indicated Sinusoids and accumulation of blood cells.

\section{Kidney}

The micrographs of kidneys of vehicle treated control animals illustrates renal corpuscles appeared dense and glomerulli surrounded by a narrow Bowman's space. Cortical tubules were observed which mainly consisted of proximal convolute tubules and with a smaller number of cortical tubules and collecting 
ducts. The average diameter of the renal corpuscles was found to be $0.3 \mu \mathrm{m}$ in all the treatment groups (Figure 3a).

A partial de-arrangement of the cortical tubule was observed in 15 day boric acid treated animals. The Bowman's space was also found to increase around the glomerulli compared to that of the vehicle treated control animals. The proximal convolute tubules and cortical tubules were also observed to be damaged. Following 30 days of boric acid treatment, complete de-arrangement of the cortical tubule was observed. The Bowman's space was significantly increasing, indicating damage to the kidneys (Figure 3b-c).

At completion of 30 days of plant extract treatment, a gradual recovery was observed in the kidneys. Bowman's space was observed to be reduce compared to that of the boric acid treated group, while in the proximal convolute tubules and cortical tubules, rearrangement was observed. A speedy recovery was observed in kidneys following 60 days of the PE treatment. The Bowman's space was reduced compared to that of the boric acid treated groups. The corpuscles rearrangement was observed to recover at a faster pace. The proximal tubules were also observed to be normal, almost comparable to that of the control group (Figure 3d-f).

\section{Tissue Biochemistry}

Significant elevation in the cholesterol content was observed at 15 and 30 days in the boric acid treated group, following the plant extract treatment, the levels were restored to the normal range comparable to that of the control group. There was a sudden decline in the protein content when treated with boric acid. Following the plant extract treatment the protein content was restored comparable to that of the control group (Table 2).

Table 2: Tissue Biochemical Analysis of Control, Boric Acid, and Plant Extract treatment groups.

\begin{tabular}{lccccc}
\hline GROUPS & CONTROL & 15 DAY BA & 30 DAY BA & 30 DAY PE & 60 DAY PE \\
\hline CHOLESTEROL & $3.4 \pm 0.04$ & $7.2 \pm 0.33^{*}$ & $8.3 \pm 0.24^{*}$ & & \\
(mg/g of tissue) & $0.7 \pm 0.03$ & $3.2 \pm 0.63^{*}$ & $4.9 \pm 0.05^{*}$ & $6.9 \pm 0.20^{* * *}$ & $2.1 \pm 0.020^{* *}$ \\
TESTIS & $0.9 \pm 0.02$ & $3.7 \pm 0.403^{* *}$ & $5.3 \pm 0.27^{*}$ & $3.2 \pm 0.43^{* *}$ & $2.0 \pm 0.028^{* *}$ \\
LIVER & & & & $4.2 \pm 0.38^{* * *}$ & \\
KIDNEY & & & & & \\
PROTEIN(mg/g & $9.3 \pm 0.28$ & $6.4 \pm 0.56^{*}$ & $5.8 \pm 0.42^{*}$ & $7.0 \pm 0.03^{* * *}$ & $8.7 \pm 0.05^{*}$ \\
of tissue) & $7.5 \pm 0.27$ & $6.3 \pm 0.25^{* *}$ & $4.5 \pm 0.22^{*}$ & $5.6 \pm 0.40^{* * *}$ & $6.80 \pm 0.63^{* * *}$ \\
TESTIS & $8.5 \pm 0.43$ & $6.2 \pm 0.62^{* *}$ & $5.3 \pm 0.33^{*}$ & $6.3 \pm 0.35^{* * *}$ & $7.38 \pm 0.022^{* *}$ \\
LIVER & & & & & \\
KIDNEY & & & & & \\
\hline
\end{tabular}

All values are mean $\pm \mathrm{SD}$ for 3 rats. $*$ : $\mathrm{p}=0.0001-0.0006, * *: \mathrm{p}=0.0007-0.005, * * *$ : $\mathrm{p}=0.006-0.05$ 

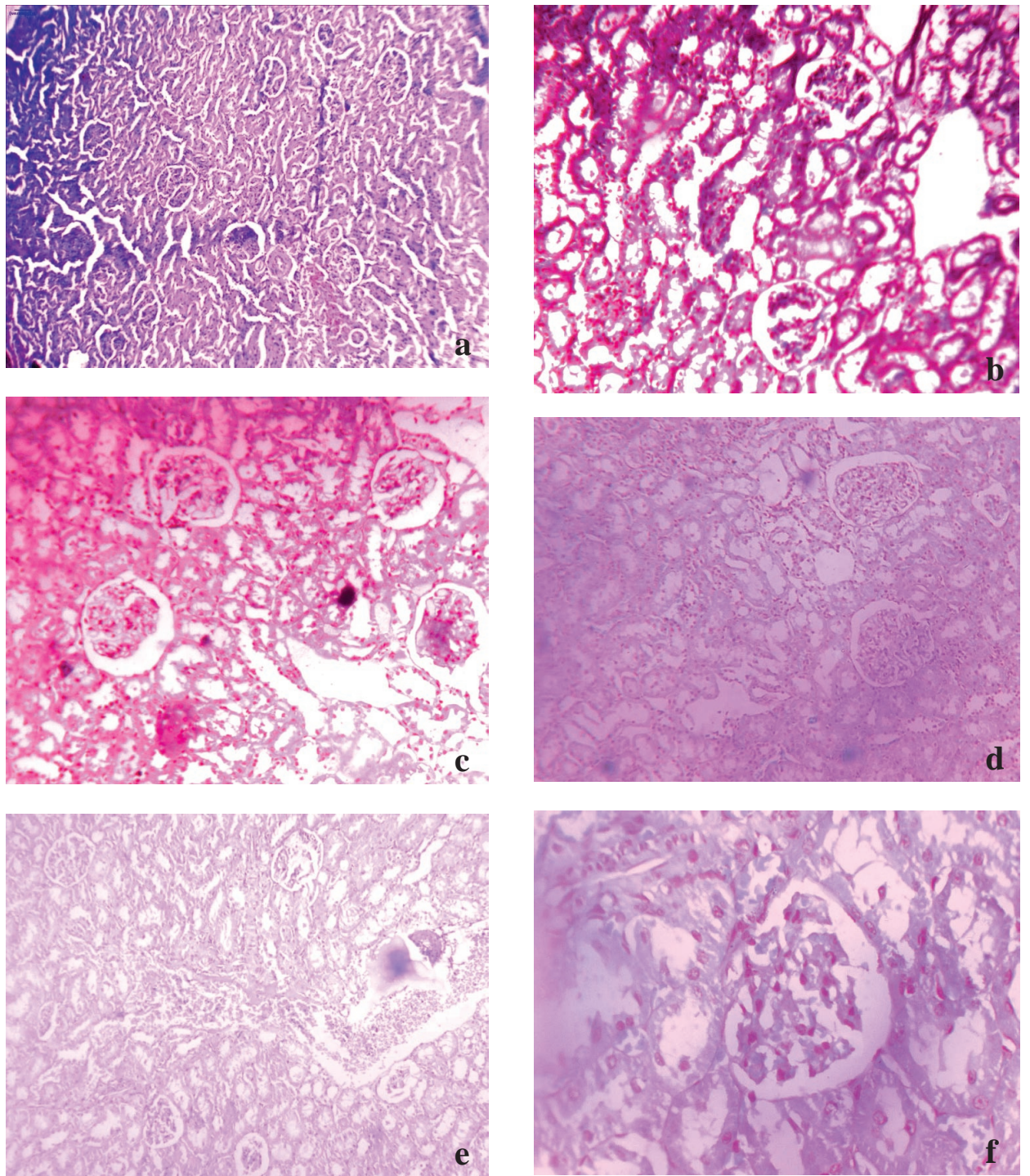

Figure 3a-f: Histological section of Kidney of Control, Boric Acid, and Plant Extract treatment groups.

\section{Antioxidant Assays}

Malondialdehyde (MDA) and Reduced Glutathione (GSH) were estimated in tissue extracts of testis to ascertain the oxidative stress at the testicular level. There was a sudden decline in the MDA level in the boric acid treated animals, but after the plant extract treatment, the level was restored to normal range comparable to that of the control group. The GSH level showed significant 
increase in boric acid treated animals but there was a sudden decline after the plant extract treatment (Graph 1).

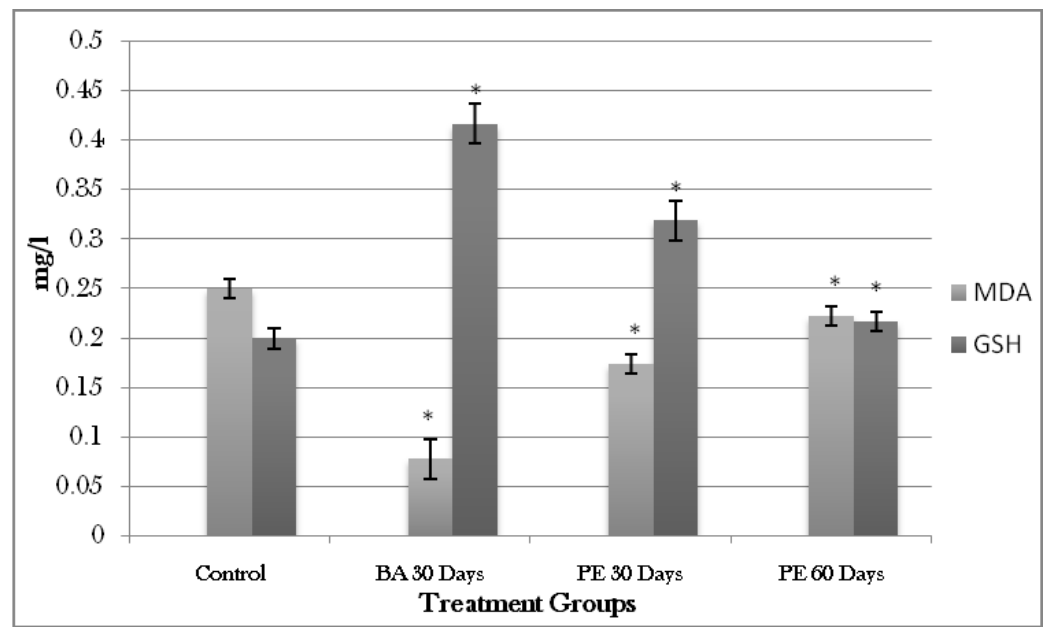

Graph 1: MDA and GSH levels of Testis of Control, Boric Acid, and Plant Extract treatment groups. All values are mean \pm SD for 3 rats. *:p?0.0001-0.0006

\section{Semenology}

The sperm count in the boric acid treated animals was found to decline, which recovered to the normal range following the plant extract treatment. The sperm were completely non-motile in the boric acid treated group, which recovered to the fertile range in the plant extract treated animals. The sperm obtained in the boric acid treated group were all dead, rendering the sperm completely infertile. The viable count increased following 30 days of extract administration and which further improved at 60 days at the end of the study period. The percentage of abnormal morphology had increased after 15 days of boric acid treatment while following the plant extract treatment, the abnormality was slightly reduced (Table 3 ).

Table 3: Semen Analysis of Control, Boric Acid, and Plant Extract treatment groups.

\begin{tabular}{|c|c|c|c|c|c|}
\hline$\overline{\text { GROUPS }}$ & CONTROL & 15 DAY BA & 30 DAY BA & 30 DAY PE & 60 DAY PE \\
\hline $\begin{array}{l}\text { Sperm count } \\
\left(10^{6} / \mathrm{ml}\right)\end{array}$ & $7.1 \pm 0.3$ & $3.2 \pm 1.21$ & $1.8 \pm 0.54$ & $8.1 \pm 0.30$ & $8.5 \pm 0.50$ \\
\hline Motility (\%) & $67.00 \pm 6$ & - & - & $57.8 \pm 5.29$ & $61.1 \pm 0.98$ \\
\hline Vitality (\%) & $66.0 \pm 2.51$ & - & - & $2.33 \pm 0.57$ & $1.0 \pm 0.23$ \\
\hline $\begin{array}{l}\text { Abnormal } \\
\text { Morphology (\%) }\end{array}$ & $10.6 \pm 1.52$ & $75.0 \pm 2.57$ & $90.8 \pm 12.73$ & $46.6 \pm 2.51$ & $37.0 \pm 2.25$ \\
\hline
\end{tabular}

All values are mean \pm SD for 3 rats. 


\section{Sperm Functional Test}

Hypo-osmotic swelling

HOS had shown significant reduction from $67 \%$ in control group to $35 \%$ in 15 days boric acid treated group i.e., the sub-fertile range. This further dropped to $2 \%$ in the 30 day boric acid treated group. However, following plant extract treatment for 30 days, the PE administered group levels were found to be in the fertile range i.e., $45 \%$, which gradually improved to $62 \%$ at the end of 60 days of the PE study period (Data not shown).

\section{Semen Biochemistry}

Following treating rats with boric acid, there was a significant increase in the LDH levels, indicating the extent of damage at the testicular level. A gradual decrease in LDH levels was observed following treatment of plant extract, values were comparable to that of the control group (Table 4).

Table 4: Seminal plasma biochemical assessment of Control, Boric Acid, and Plant Extract treatment groups.

\begin{tabular}{|c|c|c|c|c|c|c|}
\hline \multicolumn{7}{|c|}{ GROUPS } \\
\hline \multirow{7}{*}{ 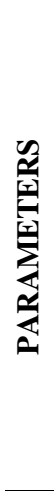 } & & CONTROL & 15 DAY BA & 30 DAY BA & 30 DAY PE & 60 DAY PE \\
\hline & LDH (unit/ml) & $53.2 \pm 0.305$ & $60.1 \pm 8.21^{*}$ & $70.0 \pm 3.40^{*}$ & $65.6 \pm 0.50$ & 58.7 \\
\hline & $\begin{array}{l}\alpha \text {-glucosidase } \\
(\mu \mathrm{mol} / \mathrm{l})\end{array}$ & $3.1 \pm 0.09$ & $1.9 \pm 0.87^{* * *}$ & $1.3 \pm 0.11^{*}$ & $1.8 \pm 0.25^{* * *}$ & $2.7 \pm 0.78^{*}$ \\
\hline & $\begin{array}{l}\text { L-Carnitine } \\
\text { (g/dl) }\end{array}$ & $0.15 \pm 0.016$ & $0.23 \pm 0.04^{* * *}$ & $0.26 \pm 0.02^{* * *}$ & $0.35 \pm 0.05^{* * * *}$ & $0.17 \pm 0.02^{* * *}$ \\
\hline & $\begin{array}{l}\text { GPC } \\
(\mathrm{mmol} / \mathrm{L})\end{array}$ & $0.31 \pm 0.018$ & $0.18 \pm 0.05^{*}$ & $0.09 \pm 0.008^{* *}$ & $0.19 \pm 0.36^{* * * *}$ & $0.25 \pm 0.06^{* * * *}$ \\
\hline & $\begin{array}{l}\text { ACP } \\
(\mathbf{U} / \mathbf{m l})\end{array}$ & $20.49 \pm 0.462$ & $17.6 \pm 1.15^{* * *}$ & $12.7 \pm 0.14^{*}$ & $18.5 \pm 0.22^{*}$ & $21.9 \pm 1.57^{*}$ \\
\hline & $\begin{array}{l}\text { Citric Acid } \\
(\mathrm{mg} / \mathrm{dl})\end{array}$ & $6.59 \pm 0.16$ & $4.2 \pm 0.8^{*}$ & $3.6 \pm 0.91^{*}$ & $3.13 \pm 0.56^{* * * *}$ & $5.4 \pm 1.24^{* * * *}$ \\
\hline
\end{tabular}

All values are mean $\pm \mathrm{SD}$ for 3 rats. $*: \mathrm{p}=0.0001-0.0006, * *: \mathrm{p}=0.0007-0.005, * * *:$ $\mathrm{p}=0.006-0.05$.

Glucosidase, seminal vesicle tissue marker decreased in the boric acid treated group which recovered following plant extract treatment. Epididymal Markers L-Carnitine and glycerophosphocholine showed a different trend. L-carnitine was found to be increasing, while there was a decrement in the GPC level in boric acid treated animals. The L-carnitine levels fluctuated whereas the GPC levels increased following plant extract treatment (Table 4).

A decrease in the activity of prostate specific acid phosphatase and citric acid was found in the boric acid treated group. The ACP values were found to increase at a steady rate following the plant extract treatment, but the citric acid levels dropped below the normal range. Although, the administration of the 
plant extract recovered the altered prostatic markers, it did not resulted in any changes with respect to the declining citric acid levels, which did not return back to normalcy even after 60 days of plant extract administration (Table 4).

\section{Blood Profiling}

\section{Hematology}

In vehicle treated control animals, all of the hematological parameters were found within the normal range. A significant decrease was observed in haemoglobin, total $\mathrm{RBC}$, platelet count, $\mathrm{PCV}, \mathrm{MCV}$, and $\mathrm{MCH}$ except for $\mathrm{MCH}$ and $\mathrm{MCHC}$ count, following boric acid treatment. Following 60 days of plant extract treatment, all the altered parameters were restored to normal ranges comparable to that of the control group. Although WBC count showed a recovery as comparable to the 30 days boric acid toxicity induced group, it did not return to normalcy until the end of the study period (Table 5).

Table 5: Hematological and hematocrit values of Control, Boric Acid, and Plant Extract treatment groups.

\begin{tabular}{|c|c|c|c|c|c|c|}
\hline \multirow{10}{*}{ 产 } & & \multicolumn{5}{|c|}{ GROUPS } \\
\hline & & CONTROL & 15 DAY BA & 30 DAY BA & 30 DAY PE & 60 DAY PE \\
\hline & $\begin{array}{l}\text { Haemoglobin } \\
\text { (gm\%) }\end{array}$ & $14.6 \pm 0.40$ & $12.1 \pm 0.35^{*}$ & $11.9 \pm 0.40^{* * *}$ & $11.0 \pm 0.05^{* * *}$ & $14.0 \pm 0.35^{* *}$ \\
\hline & $\begin{array}{l}\text { Total W.B.C } \\
\left(10^{3} / \text { c.mm }\right)\end{array}$ & $11.7 \pm 0.56$ & $2.5 \pm 0.80$ & $1.9 \pm 0.02$ & $4.9 \pm 0.90$ * & $6.9 \pm 0.40^{*}$ \\
\hline & $\begin{array}{l}\text { Total R.B.C } \\
\left(10^{6} / \text { C.mm }\right)\end{array}$ & $7.8 \pm 0.07$ & $6.1 \pm 0.16^{*}$ & $5.1 \pm 0.08$ & $6.2 \pm 0.20^{*}$ & $7.1 \pm 0.20^{*}$ \\
\hline & $\begin{array}{l}\text { Platelet Count } \\
\left(10^{6} / \mathrm{c} . \mathrm{mm}\right)\end{array}$ & $7.0 \pm 0.07$ & $4.3 \pm 0.31 *$ & $6.0 \pm 0.34^{* *}$ & $7.0 \pm 0.81^{* *}$ & $7.9 \pm 0.02^{* *}$ \\
\hline & P.C.V $(\%)$ & $46.6 \pm 0.66$ & $34.0 \pm 5.56^{* * * *}$ & $29.6 \pm 6.5^{* *}$ & $31.2 \pm 0.17$ & $41.5 \pm .31^{* * *}$ \\
\hline & M.C.V (fl) & $60.0 \pm 0.98$ & $55.7 \pm 0.50^{* * *}$ & $52.1 \pm 0.87^{*}$ & $50.9 \pm 0.16^{* * *}$ & $53.5 \pm 0.16^{* * * *}$ \\
\hline & M.C.H (pg) & $18.7 \pm 0.40$ & $19.8 \pm 0.60^{* * *}$ & $23.0 \pm 0.15^{* *}$ & $21.2 \pm 0.87^{* * * *}$ & $18.3 \pm 0.28^{*}$ \\
\hline & M.C.H.C (\%) & $31.3 \pm 0.55$ & $34.6 \pm 0.55^{*}$ & $38.7 \pm 0.32^{*}$ & $31.1 \pm 0.08^{*}$ & $34.6 \pm 0.58^{* * *}$ \\
\hline
\end{tabular}

All values are mean $\pm \mathrm{SD}$ for 3 rats. $*: p=0.0001-0.0006, * *: p=0.0007-0.005$, $* * *$ : $\mathrm{p}=0.006-0.05$.

\section{Serum Biochemistry}

Serum biochemical analysis of the control group for Glucose, Protein, HDL cholesterol, Triglyceride, Creatinine, Urea, Total Bilirubin, Direct Bilirubin, serum glutamate pyruvate transaminase (SGPT), Serum glutamate oxaloacetate transaminase (SGOT), and Creatinine kinase-MB showed these values within the normal physiological range. The values obtained were $103.6 \pm 0.17 \mathrm{mg} / \mathrm{dl}, 8.3 \pm 0.26 \mathrm{~g} / \mathrm{dl}$, $165.8 \pm 7.16 \mathrm{mg} \%, 61.6 \pm 0.73 \mathrm{mg} / \mathrm{dl}, 2.0 \pm 0.70 \mathrm{mg} / \mathrm{dl}, 5.0 \pm 0.30 \mathrm{mg} / \mathrm{dl}, 4.3 \pm 0.27 \mathrm{mg} / \mathrm{dl}$, $1.9 \pm 0.21 \mathrm{mg} / \mathrm{dl}$ and $4.59 \pm 0.22 \mathrm{U} / \mathrm{IAST}, 4.6 \pm .20 \mathrm{U} / \mathrm{IALT}$ and $18.02 \pm 0.09 \mathrm{U} / \mathrm{I}$, respectively. 
Following 15 days and 30 days boric acid treatment, all serum enzyme activity i.e., SGOT, SGPT and CK-MB, were found to increase and the nonenzymatic parameters showed significant decrease at the end of the 30. Following administration of the plant extract, all of the altered parameters were restored back to normalcy (Table 6).

Table 6: Serum Biochemical Analysis of Control, Boric Acid, and Plant Extract treatment groups.

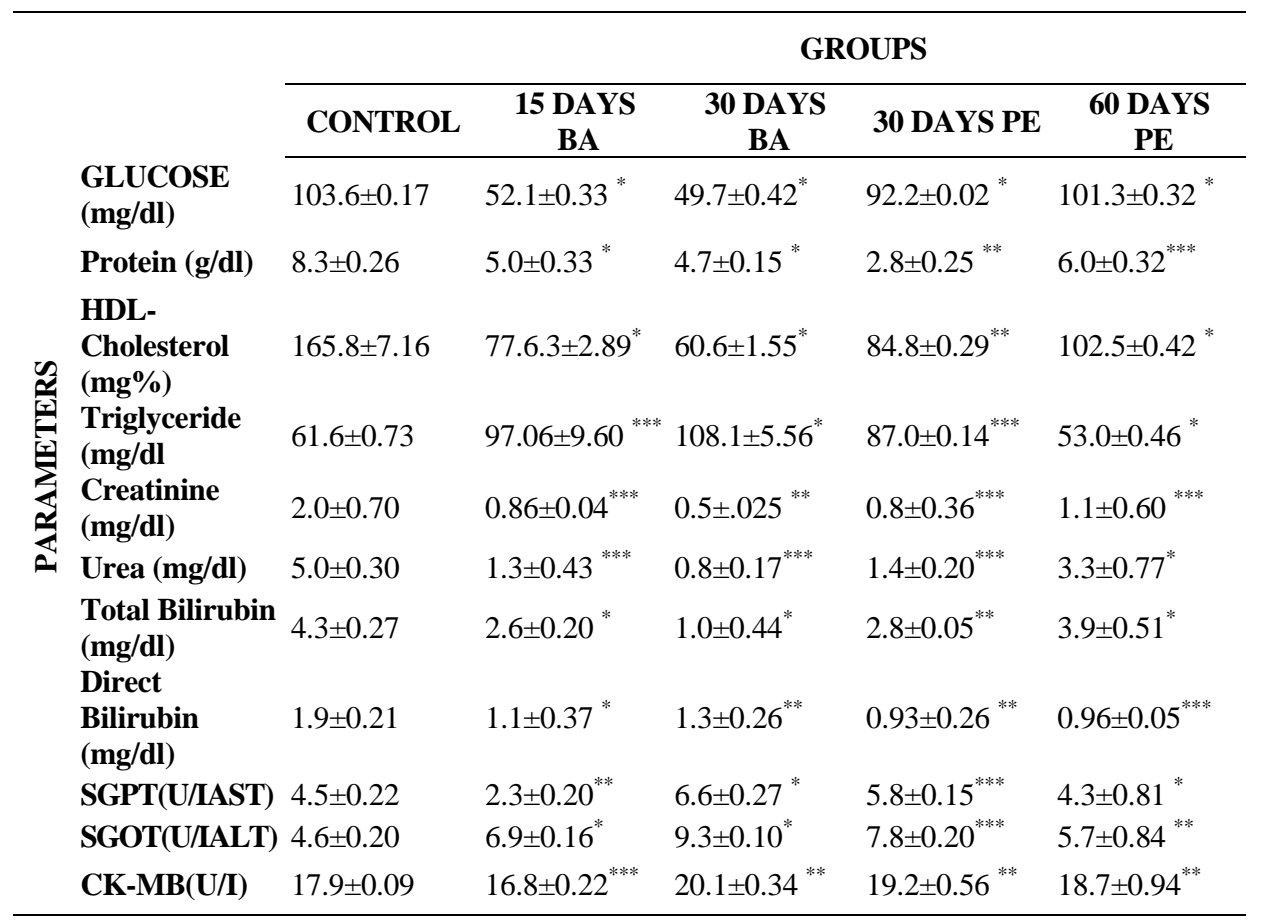

All values are mean $\pm \mathrm{SD}$ for 3 rats. $*: \mathrm{p}=0.0001-0.0006, * *: \mathrm{p}=0.0007-0.005$, $* * *: \mathrm{p}=0.006-0.05$.

\section{Hormone Analysis}

The serum testosterone estimation was concurrent to the alteration in the serum biochemical parameters, which showed a drop following boric acid treatment and improved significantly following the plant extract treatment. The concentration obtained for the vehicle treated control group and boric acid treated group were $1.08 \pm 0.05 \mathrm{ng} / \mathrm{ml}$ and $0.59 \pm 0.04 \mathrm{ng} / \mathrm{ml}$ respectively. The value estimated following 30 days and 60 days of plant extract treatment was found to be $0.71 \pm 0.05 \mathrm{ng} / \mathrm{ml}$ and $1.09 \pm 0.02 \mathrm{ng} / \mathrm{ml}$, respectively (Table 7).

The estrogen concentration in vehicle treated animals was $47.485 \pm 0.23 \mathrm{pg} / \mathrm{ml}$, while the level was found to be decreasing in 30 day boric acid and plant extract treated animals. The values estimated were $32.0 \pm 2.54 \mathrm{pg} / \mathrm{ml}$ and $24.84 \pm 1.34 \mathrm{pg} / \mathrm{ml}$ 
respectively. After 60 days of plant extract treatment, the value estimated was $38.5 \pm 2.22 \mathrm{pg} / \mathrm{ml}$ which indicates that there was significant improvement in comparison to the boric acid treated group (Table 7).

The FSH concentration in vehicle treated animals and boric acid treated animals were $0.32 \pm 0.035 \mathrm{mIU} / \mathrm{ml}$ and $0.33 \pm 0.030 \mathrm{mIU} / \mathrm{ml}$ respectively. A sudden decrease in the level was observed after 30 days of plant extract treatment. The value estimated on the $30^{\text {th }}$ day of plant extract treatment was $0.11 \pm 0.04 \mathrm{mIU} / \mathrm{ml}$. After 60 days of plant extract treatment, the level was restored to normal range and estimated value was $0.3 \pm 0.02 \mathrm{mIU} / \mathrm{ml}$ (Table 7).

Table 7: Testesterone, Estrogen and FSH levels of Control, Boric Acid, and Plant Extract treatment groups.

\begin{tabular}{llll}
\hline \multicolumn{1}{c}{ Treatment Groups } & \multicolumn{1}{c}{$\begin{array}{c}\text { Testosterone } \\
(\mathbf{n g} / \mathbf{m l})\end{array}$} & \multicolumn{1}{c}{ Estrogen $(\mathbf{p g} / \mathbf{m l})$} & \multicolumn{1}{c}{ FSH (mIU/ml) } \\
\hline Control & $1.08 \pm 0.05$ & $47.485 \pm 0.23$ & $0.32 \pm 0.035$ \\
Boric Acid 30 days & $0.59 \pm 0.04 *$ & $32.0 \pm 2.54 *$ & $0.33 \pm 0.030 *$ \\
Plant Extract 30 days & $0.71 \pm 0.05 * * *$ & $24.84 \pm 1.34 * *$ & $0.11 \pm 0.04 * *$ \\
Plant Extract 60 days & $1.09 \pm 0.02 *$ & $38.5 \pm 2.22 * * *$ & $0.3 \pm 0.02 * * *$ \\
\hline
\end{tabular}

All values are mean $\pm \mathrm{SD}$ for 3 rats. $*: \mathrm{p}=0.0001-0.0006, * * *: \mathrm{p}=0.006-0.05$.

\section{DISCUSSION}

Boric acid is a suspected reproductive toxicant. Boric acid generally is of moderate acute toxicity, and has been placed in Toxicity Category III for most acute effects including oral and dermal toxicity, and eye and skin irritation. Most poisonings by boric acid have occurred in connection with its former use as a local antiseptic applied to irritated skin, burns, or wounds. The fatal dose is thought to be 2,000-3,000 $\mathrm{mg}$ for infants, 5,000-6,000 $\mathrm{mg}$ for children and 15,000-20,000 mg for adults. The (US, India) EPA classified boric acid as a "Group E" carcinogen, indicating that it shows "evidence of noncarcinogenicity" for humans (FISHEL 2005).

Eclipta alba is a drought tolerant small evergreen tree of the family asteraceae with a wide geographical and ecological distribution. Certain parts of the plant are used as medicinal materials. This plant grows as a common weed throughout India. Its phytochemical constituents are: wedelolactone, demethyl-wedelolactone, stigmasterol, -terthienymethanol, desmethyl-wedelolactone-7-glucoside, apigenin, luteolin and its glucoside, wedelic acid, 25-hydroxyver azine, ecliptine, nicotine, and an unnamed alkaloid (WAGNER et al. 1986). Roots of E. alba have been reported to contain thiophene acetylenes such as 5I-senecioyl oxymethylene-2(4-isovaleryloxybut-3-ynyl)- dithiophene, 5I-tigloyloxymethylene- (isovaleryloxybut3-ynyl) dithiophen and 2-(3-acetoxy-4-chloro-but-1-ynyl)-5-(pent-1,3-diynyl) thiophene, hentriacontanol, stigmasterol, ecliptal, and 14-heptacosanol. Stems 
contain wedelolactone, wedelic acid, L-terthienyl methanol, apigenin, and luteolin. Seeds of E. alba contain sterols (Khare 2004, Kapoor 2001).

$E$. alba extract has been used for ascertaining various biological activities such as anti-bacterial effect (Phadke and KulKarni 1989, Farouk et al. 1983), Anti-hepatitis activity (Ministry of Health and Family Welfare Government of India 2001), anti-hyperglycemic effect (THоRAт et al. 2010), and hepatoprotective activity (Chaudhary et al. 2011, Thorat et al. 2010).

Numerous properties of E. alba are known from literature, but there are no reports available with respect to the efficacy of $E$. alba extract on the male reproductive system. Therefore, to determine its potential effects in reversal of reproductive toxicity this study was designed and carried out.

Although food and water intake had increased, there was a notable drop in the body weight of boric acid treated animals. The cause for this is unknown. According to a report by AYSAn et al., (2011), low-dose $(0.2 \mathrm{mg} / \mathrm{kg})$ oral boric acid intake caused serious body weight reduction after five days. A toxicology study by the US Department of Health and Human Services demonstrated that a 275 to $550 \mathrm{mg}$ of boric acid per $\mathrm{kg}$ of body weight per day intake reduced mouse body weights $10-17 \%$ after 32 weeks.

After treatment with boric acid, profound testicular changes were observed. The internal arrangement of the seminiferous tubules were completely damaged. This indicates that the Sertoli cells located in tubules were damaged, consequentially, sperm generation and maturation were also disturbed, which was observed by studying semenology. No sperm accumulation was observed indicating dysfunction of the Sertoli cells. The interstitial space was observed to be damaged. Hence, Leydig cells located in the interstitial space were also degenerated. The results obtained in this study were found to be similar to those reported by Traina et al. (2003) and Ronco et al. (2001). Suwalsky et al. (2000) reported an increase in the size of Leydig cells following lindane treatment, contradictory to our study which revealed the degeneration of the leydig cells, which was similar to findings reported by Ananya et al. (2005).

A gradual and slow re-development of testis was observed following the plant extract treatment. On completion of the treatment, the arrangement of the Sertoli cells in the seminiferous tubules was almost comparable to that of the vehicle treated control animals. Sperm accumulation was also observed and the semenology study revealed that sperm generated were properly matured indicating the proper functioning of the Sertoli cells, which were degenerated following the boric acid treatment. The interstitial space was also observed to redevelop following the plant extract treatment. This indicates that Leydig cells were regenerated following the plant extract treatment.

Fail et al. (1998), emphasize that few studies exist on the chronic effects of boron in humans and a similar number in experimental animals, most of which are focused on its reproductive and developmental effects. The most documented reproductive damage corresponds to alterations of the spermatogenesis and degeneration of the seminiferous epithelium, indicating the necessity to extend the study of the toxicity of boron to other tissues. 
The toxic effect of boron occurs beyond the function of the hepatocytes, altering the production of collagen on the part of Ito, fibroblasts, and endothelial cells (Bustos-Obregón et al. 2008).

Profound histological changes were observed in 30 days boric acid treated animals. The inter hepatocyte spacing was noted to increase following the boric acid treatment. This may due to disturbance in the cell to cell interaction by inhibition of the gap junction. The blood supply to the cell was also disturbed and cellular clumps were visible. The protective cushioning collagenous tissue was also not observed in the liver.

A proper re-arrangement of the tissue was observed following the plant extract treatment. The gradual redevelopment of the blood supply was observed in the cells. The portal tract was observed to be normal indicating that the blood supply was almost comparable to that of vehicle treated control animals. The clumps were not observed after 60 days of plant extract treatment. The cellular arrangement was observed to be regular, indicating restoration of the gap junction and cellular interaction. Thus plant extract treatment reveals the hepatoprotective properties of the plant extract.

The basic unit of the kidney is the nephron, consisting of renal corpuscles (initial filtering component). Boric acid treatment has increased the Bowman's space in renal corpuscles and also disturbed the PCT and DCT. The concentration of the urea was also observed to be altered indicating renal failure.

During the course of the plant extract treatment, a gradual recovery was observed in the kidneys. At the end of the treatment, Bowman's space was almost comparable to that of the vehicle treated control animals. Proper arrangement of the PCT and DCT were also observed, indicating the proper functioning of the nephron. Thus, after plant extract treatment, the nephropathy had been observed to be reversed and proper functioning of nephrons was reestablished.

Significant elevation in the tissue cholesterol content was observed following 30 days of boric acid treatment. The concentrations of cholesterol, an essential structural component of membranes and the precursor of all steroid hormones, may increase due to liver and kidney failure causing the release of cholesterol into the blood. The result found in the present study is concurrent to the results observed by FURAT et al. (2011), which reported that the total cholesterol content increased in Oreochromis niloticus, a fish, when exposed to a pesticide, cypermethrin and two metals (copper and lead). After 60 days of plant extract treatment, the cholesterol content returned to a normal range compared to that of the vehicle treated control animals.

The histological observations were confirmed by the tissue biochemical parameters. Following boric acid treatment, a significant decline in the protein content of the tissue was noted. This might be due to inhibition of protein synthesis.

Tissue biochemistry in all treatment groups was performed to determine the oxidative stress prevailing in the tissue. ROS (reactive oxygen species) are an important part of the defense mechanism against infection, but excessive generation of free oxygen radicals may damage tissues. ROS are formed in both physiological and pathological conditions in mammalian tissues. ROS include 
superoxide anion, hydroxyl radical, hydrogen peroxide, and oxygen ion, all of which are unstable and fully reactive to attack molecules in the body resulting in ROS conversion to stable atoms and molecules (IchiKawa et al. 1999). When the balance between ROS and the antioxidant system is lost, «oxidative stress» results (BANDYOPADHYAY et al. 1999). Oxidative stress is one of the major factors for induction of cancer (KLAUNIG et al. 1998).

The MDA levels are determined as an index of Lipid peroxidation and it is one of the main manifestations of the toxicity and carcinogenesis of many carcinogens (RASTOGi et al. 2001; Grammatikos et al. 1994). The marked increase in MDA content after aflatoxin $\mathrm{B} 1 \mathrm{AFB}_{1}$ ) exposure could contribute to the effect on the antioxidant defense system (TURKEz et al. 2010). On the contrary in our studies, there is a decrement in the MDA level in testis and prostate following 30 days of boric acid treatment.

After the boric acid treatment, the GSH concentration was found to decline in the epididymis and prostate, whereas in the testis there was a significant elevation. The variation observed in GSH, indirectly indicated high generation of free radicals in the tissue, which was also observed by Turkez et al. (2010). This may cause decreased degradation of lipid peroxides leading to their accumulation thus amplifying the toxicity.

Following the treatment with plant extract, the concentration of GSH and MDA was observed to return to normalcy. This indicates the there is a decline in free radical generation. Thus the plant extract exhibits a free radical scavenging property, and helps in maintaining the relationship between exogenous and endogenous ROS, reducing the oxidative stress on the tissue. A similar result was reported by AHмеD et al. (2008) using extract of Zingiber officinales in a liver antioxidant study.

A decrease in the epididymal sperm count was observed following the boric acid treatment which was also observed by PRASAD et al. (1995). Sperm viability was also observed to decline along with the sperm functionality test. This indicates the induction of infertility in male rats in the boric acid treated groups. A similar result was observed by FAUSTO et al. (2001) in male rabbits. The decrease in the epididymal sperm count can also be confirmed with the histopathological studies of testis.

A complete reversal or restoration of the activity of sperm and sperm function was observed comparable to that of the vehicle treated control animals following the plant extract treatment. The viability was observed to be restored to almost comparable to that of the vehicle treated control. The sperm count was observed to be normal following plant extract treatment. A regeneration of the proper arrangement of the testis was also observed. The sperm functional analysis was also noted to be almost comparable to vehicle treated control animals.

LDH-C4 is an isoenzyme associated with the testis, normally used as a marker for determining proper functioning of the reproductive organs (SAWANE et al. 2002). An increase in the LDH-C4 value indicates that sperm mitochondrial activity has declined; indicating improper functioning of the sperm and its maturation. Analysis of semen biochemistry showed an increased value of LDH- 
$\mathrm{C} 4$ in boric acid treated animals group. The increase in the activity of LDH-C4 indicates function of the mitochondria had been hampered. Moreover LDH plays a major role in metabolic activity (glycolysis). Rupturing of the spermatids, results in release of contents from sperm head, neck, and midpiece. Thus, leading to an increase in the LDH activity.

Estimation of á-glucosidase activity in semen is widely used as a marker of epididymal function (Kalla et al. 1997). Epididymal á-glucosidase does not play a crucial role in the development of sperm fertilizing capacity, but may be involved in the preparation of spermatozoa for storage (Yeung and Copper 1994). Decrease in the enzymes activity has been observed in non-azoospermic men (GUERIN et al. 1990). A decrease in the activity was observed in the boric acid treated animals, indicating conditions of infertility in the animals.

The epididymal marker, L-carnitine was found to be increasing in the boric acid treated animals. This is because L-carnitine has antioxidant potentials thereby protecting against oxidative stress (SIKTAR et al. 2011). The increase in L-carnitine levels were also confirmed by an increase in antioxidant levels and damage caused in the epididymis.

The other epididymal marker, GPC was found to be decreasing following the boric acid treatment. GPC has a role in motility of the sperm (INFANTE et al., 1985). A decrease in GPC levels results in reduction of motility which is concurrent to the results obtained in the present study.

A decrease in the activity of prostate specific, acid phosphatase and citric acid was found in boric acid treated animals. Acid phosphatase is associated with sperm motility (ANDO et al. 1990). This indicates a decline in the sperm motility due to a decrease in ACP activity. Hypo-osmotic swelling test is also used to determine sperm motility (JEYENDRAN et al. 1984). A reduction in the coiling was observed in the boric acid treated animals, justifying the reduction in ACP activity.

A significant decrease was observed in haemoglobin, total RBC, platelet count, $\mathrm{PCV}, \mathrm{MCV}$, and $\mathrm{MCH}$ except for $\mathrm{MCH}$ and $\mathrm{MCHC}$ count, following boric acid treatment. Decrease in hemoglobin in experimental animals might be due to destruction of erythrocytes and inhibition of erythropoiesis, which is confirmed by decreased MCHC Values. Similarly, significant decrease in the haematological parameters was observed in fish when exposed to Sevin, a pesticide (PATNAIK and Patra 2006).

After 60 days of plant extract treatment, all of the altered parameters were restored to normal ranges comparable to that of the control group.

Boric acid was observed to have damaged the function of tissues, namely liver, kidney, and testis. Hence, there was a drastic change in the serum profile of the animals. The serum enzymes, namely alkaline CK-MB, SGOT, and SGPT were observed to increase drastically after the boric acid treatment. The increase in the enzymes indicates the functioning of the hepatocytes had been disturbed, releasing the enzymes into the circulatory system.

The non-enzymatic parameters showed a significant decrease at the end of 30 days of boric acid treatment. The concentration of glucose was observed to decrease. Thus treatment with boric acid aroused a hypoglycemic condition, 
indicated that the glycogen metabolism and gluconeogenesis has been disturbed. The insecticide, thiamethoxam, has been found to cause a reduction in serum cholesterol that precedes liver histopathological changes similar to those observed in the present study (GREEN et al. 2005). These authors interpreted the low cholesterol as an early sign of liver dysfunction. Glucose, cholesterol, and HDL cholesterol were also observed to decrease. The primary purpose of HDL is to act as an acceptor of cholesterol released from tissues outside the liver and transport it back to the liver (MikHAILIDIS and WierzBicki 2000). HDLcholesterol is not recycled for cholesterol uptake from different tissues indicating an imbalance in the cholesterol metabolism. The concentration of urea was noted to be decreasing following the boric acid treatment. The decrease in the serum urea level indicates impairment in kidney/nephron function, which was also observed in the histopathological study of the kidney.

The plant E.alba has been shown to have hepatoprotective activities (Thorat et al. 2010). After treatment with the plant extract, the activity of the serum enzymes was observed to be restored to normalcy. This indicates repair of the damaged tissue following the treatment. The concentration of cholesterol and HDL-cholesterol was also observed to increase after the course of plant extract treatment. Similar results were obtained when Physalis angulata was administered to rats (CHOI and HwANG 2005). In the present investigation, the concentration of urea was restored to normalcy after 60 days of treatment, indicating recovered functioning of the nephron.

The serum testosterone estimation was concurrent to the alteration in the serum biochemical parameters, which showed a drop following boric acid treatment and improved significantly following the plant extract treatment. Testosterone is specifically produced by Leydig cells containing enzyme 11â-hydroxysteroid dehydrogenase ( $\mathrm{GE}$ et al. 2005). The concentration of testosterone was observed to decline after the 30 days of boric acid treatment. Histological studies of the testis revealed the degeneration of Leydig cells during the boric acid treatment, which is confirmed by decline in testosterone level; compared to that of the vehicle treated control animals. Following the plant extract treatment, regeneration of the Leydig cells was observed, which was confirmed by an increase in the testosterone level, almost comparable to that of the vehicle treated control animals.

Elevations in serum FSH levels suggested an intact hormonal response to the testicular atrophy (Ku et al. 1994). There was slight elevation in FSH levels after 30 days of boric acid treatment. Following the 30 days of plant extract treatment, the level declined, which was restored to the normal range after 60 days of plant extract treatment. Serum FSH levels were lower in animals treated with plant extracts of Cynomorium coccineum and Withania somnifera (ABDELMAGiED et al. 2001). Another report by Udoh et al. (2009), states that when an alkaloid extract of caricapryl-99 seeds was administered to male albino rats, it caused an increase in serum levels of FSH and estrogen.

Thus with the treatment of boric acid in rats, the functioning of male reproductive organs is completely hampered and the animals became astheno- 
necrozoospermic. Boric acid not only affects the testis but also inhibits the functioning of vital organs such as the liver and kidneys. Thus, the above results reveal that boric acid induces hepato and nephropathy and is also a potent reproductive toxicant. Following treatment of the boric acid treated animals with the hydroalcoholic plant extract, a reversal in the damaged histoarchitecture of the tissue was observed. During the treatment period, a decline in oxidative stress was also observed. Reproductive toxicological effects induced by the boric acid was also observed to be completely recovered following plant extract treatment. Hence, the extract can be used for the reversal of reproductive toxicity.

\section{Acknowledgement}

The authors are grateful for the financial assistance from Nirma Education \& Research Foundation (NERF), Ahmedabad for the present investigation. The present investigation is a part the Dissertation Thesis of Ms. PooJA NAIR submitted to Nirma University, Ahmedabad.

\section{UWODNIONY EKSTRAKT ALKOHOLOWY ECLIPTA ALBA JAKO CZYNNIK ODWRACAJĄCY INDUKOWANĄ TOKSYCZNOŚĆ KWASU BOROWEGO NA ROZRODCZOŚĆ SAMCÓW U SZCZURÓW}

\section{STRESZCZENIE}

Podawanie kwasu borowego szczurom ma szkodliwy wpływ na narządy płciowe, wątrobę i nerki. W celu przetestowania antytoksycznych właściwości eklipty (Eclipta alba), samcom szczurów rasy Wistar podawano doustnie kwas borowy $(350 \mathrm{mg} / \mathrm{kg}$ masy ciała) przez okres 30 dni, po czym część zwierząt traktowano przez okres dwóch miesięcy uwodnionym ekstraktem alkoholowym z eklipty w dawce $500 \mathrm{mg} / \mathrm{kg}$ masy ciała. W grupie zwierząt, której podawano tylko kwas borowy, obserwowano toksyczne zmiany takie jak: uszkodzenia wątroby, nefropatie, czy całkowite uszkodzenia jąder, narastające od 15 dnia traktowania kwasem aż do ostatniego dnia badań. Zanotowano również wzrost stresu oksydacyjnego we wszystkich istotnych narządach wewnętrznych. Podanie ekstraktu roślinnego w drugiej grupie zwierząt, prowadziło do całkowitego odwrócenia toksycznych zmian w narządach rozrodczych. Poziom hormonów tj.: testosteronu, estrogenów, i FSH, oraz płodność badanych szczurów powróciły do normalnych wartości po sześćdziesięciodniowym okresie podawania ekstraktu roślinnego. W porównaniu do zwierząt kontrolnych (niepoddanych żadnym manipulacjom) obserwowano również istotne odwrócenie zmian związanych ze stresem oksydacyjnym w narządach wewnętrznych oraz w morfologii analizowanych pod mikroskopem świetlnym tkanek. Podanie ekstraktu roślinnego z eklipty prowadziło zatem do całkowitego odwrócenia zmian wywołanych toksycznym działaniem kwasu borowego. Otrzymane wyniki wskazują na nowe, regeneracyjne możliwości ekstraktu z Eclipta alba w sytuacji znacznego uszkodzenia układu rozrodczego samców szczurów. Jednakże, dokładne poznanie aktywnych czynników ekstraktu oraz mechanizmy ich działania wymagają dalszych badań. 


\section{REFERENCE}

Abdel-Magied E.M., Abdel-Rahman H.A. and Harraz F.M. 2001: The effect of aqueous extracts of Cynomorium coccineum and Withania somnifera on testicular development in immature Wistar rats. J. Ethnopharmacol., 75(1):1-4.

Ahmed R.S., Suke S.G., Seth V., Chakraborti A., Tripathi A.K. and Banerjee B.D. 2008: Protective effects of dietary ginger (Zingiber officinales Rosc.) on lindane-induced oxidative stress in rats. Phytother. Res., 22(7): 902-906.

Amin A. and Hamza A.A. 2006: Effects of Roselle and Ginger on cisplatin-induced reproductive toxicity in rats. Asian J. Androl., 8(5): 607-612.

Ananya R., Subeena S., Kumar D.A., Kumar D.T. and Kumar M.S. 2005: Oxidative stress and histopathological changes in the heart following oral lindane (gamma hexachlorohexane) administration in rats. Med. Sci Monit. 11(9): BR325-9.

Ando S., Carpino A., Buffone M., Maggiolini M., Giacchetto C. and Seidita F. Fructose 1990: Prostatic acid phosphatase and zinc levels in the seminal plasma of varicoceles., Int. J. Fert. 35(4): 249-52.

Aysan E., Sahin F., Telci D., Yalvac M.E., Emre S.H., Karaca C. and Muslumanoglu M. 2011: Body Weight Reducing Effect of Oral Boric Acid Intake. Int. J. Med. Sci., 8(8): 653-658.

Bandyopadhyay U., Das D., and BanerJee R.K. 1999: Reactive oxygen species; oxidative and pathogenesis., Curr. Sci. 77: 658-66.

Beutler E. and Yeh M.K.Y. 1994: Erythrocyte glutathione reductase. Blood, 21: 573-585.

Bustos-Obregón E., Belmar R.H. and Catriao-Gálvez R. 2008: Histopathological Effects of Boron on Mouse Liver. Int. J. Morphol., 26(1): 155-164.

CHAPIN R.E. and KU W.W. 1994: The reproductive toxicity of boric acid. Environ. Health Perspect., 102(Suppl 7): 87-91.

Chaudhary H., Dhuna V., Singh J., Kamboj S.S. and Seshadri S. 2011: Evaluation of hydro-alcoholic extract of Eclipta alba for its anticancer potential: an in vitro study. J Ethnopharmacol., 136: 363-367.

Chor E.M. and Hwang J.K. 2005: Effect of some medicinal plants on plasma antioxidant system and lipid levels in rats. Phytother. Res., 19(5): 382-386.

Creasy D.M. 2001: Pathogenesis of Male Reproductive Toxicity. Toxicol. Pathol., 29(1): 64-76.

Fail P., Chapin R.E., Price C.J. and Heindel J.J. 1998: General, reproductive, developmental, and endocrine toxicity of boronated compounds. Reprod. Toxicol., 12(1): 1-18.

Farouk A., Bashir A. and SAlih A. 1983: Antimicrobial activity of certain Sudanese plants used in folkloric medicine. Screening for antibacterial activity (I)., Fitoterapia 54: 3-7.

Fausto A.M., Morera P., Margarit R. and Taddei A.R. 2001: Sperm quality and reproductive traits in male offspring of female rabbits exposed to lindane (gamma-HCH) during pregnancy and lactation. Reprod. Nutr. Dev., 41(3): 217-25

Fishel F.M. 2005: Pesticide Toxicity Profile: Boric Acid. Institute of Food and Agricultural Sciences, University of Florida, PI-91: 1-3.

Fukuda R., Hirode M., Mori I., Chatani F., Morishima H. and Mayahara H. 2000: Collaborative work to evaluate toxicity on male reproductive organs by repeated dose studies in rats-Testicular toxicity of boric acid after 2- and 4-week administration periods. J. Toxicol. Sci., 25: 233-239. 
Furat O., Cogun H.Y., YüzereroĐlu T., Gök G., Kargin F. and Kötemen Y. 2011: A comparative study on the effects of a pesticide (cypermethrin) and two metals (copper, lead) to serum biochemistry of Nile tilapia, Oreochromis niloticus. Fish Physiol. Biochem., 37(3): 657-66.

Gavella M. 1988: Simple, rapid determination of zinc and acid phosphatase in seminal plasma with ABA-100 biochromatic analyzer. Clin. Chem., 34(8): 1605-1607.

Ge R., Dong Q., Niu E., Sottas C., Hardy D., Catterall J., Latif S., Morris D. and HaRdY M. 2005: 11ß-hydroxysteroid dehydrogenase 2 in rat leydig cells; its role in blunting glucocorticoid action at physiological levels of substrate. Endocrinol., 146(6): 2657-2664.

Grammatikos S.I., Subbaiah P.V., Victor T.A. and Miller W.M. 1994: Diverse effects of essential (n-6 and n-3) fatty acids on cultured cells. Cytotechnol., 15: 31-50.

Green T., Toghill A., Lee R., Waechter F., Weber E. and Noakes J. 2005: Thiamethoxam Induced Mouse Liver Tumors and Their Relevance to Humans. Part 1: Mode of Action Studies in the Mouse. Toxicol. Sci., 86(1): 36-47.

Guerin J., Ben A.H., Cottinet D. and Rollet J. 1990: Seminal alpha-glucosidase activity as a marker of epididymal pathology in nonazoospermic men consulting for infertility. J Androl., 111(3): 240-245.

Ichikawa T., Oeda T., Ohmori H. and Schill W.B. 1999: Reactive oxygen species influences the acrosome activity in human spermatozoa. Int. J. Androl., 2(1): $37-42$.

Infante J.P. and Huszagh V.A. 1985: Synthesis of highly unsaturated phosphatidylcholines in the development of sperm motility: a role for epididymal glycerol-3phosphorylcholine. Mol. Cell. Biochem., 69(1): 3-6.

International Programme on Chemical Safety (IPCS). Organización Mundial de la Salud. Environmental health Criteria 204 Boron. World Health Organization, 192201, Geneva, 1998 .

Jeyendran R.S., Vander-Ven H.H., Perez-Pelaez M., Crabo B.G. and Zaneveld L.J. 1984: Development of an assay to assess the functional integrity of the human sperm membrane and its relationship to other semen characteristics. J. Reprod. Fertil., 70(1): 219-228.

Kalla N., Kaur S., Ujwal N., Mehta U., Joos H. and Frick J. 1997: Alpha-glucosidase activity in the rat epididymis under different physiological conditions. Int. J. Androl., 20(2): 92-95.

Kapoor L.D. 2001. Handbook of Ayurvedic Medicinal Plants, (CRC Press LLC).

Kempinas W.G. and Lamano-Carvalho T.L. 1988: A method for estimating the concentration of spermatozoa in the rat cauda epididymidis. Lab. Animals, 22: 154-156.

Khare C.P. 2004: Encyclopedia of Indian Medicinal Plants. Springer Verlag Berlin Heidelberg, New York.

KIng E.J. and Wootton I.D.P (Eds). 1956: Microanalysis in medical biochemistry. Churchill Press, London, 3rd Edition, 42 (1956).

Klaunig J., Xu Y., Isenberg J., Bachowski S., Kolaja K., Jiang J., Stevenson D. and WALborg JR.E. 1998: The role of oxidative stress in chemical carcinogenesis. Environ. Health Persp., 106: 289-295.

Ku W.W., Chapin R.E., Wine R.N. and Gladen B.C. 1993: Testicular toxicity of boric acid (BA): relationship of dose to lesion development and recovery in the F344 rat. Reprod. Toxicol., 7(4): 305-19.

Lowry O.H., Rosenbrought D.J., Farr A.L. and Randall R.J. 1951: Protein measurement with the Folin-Phenol reagents. J Biol. Chem., 193: 265-275. 
Lynch M.J., Raphael S.S., Mellor L.D., Spare P.D. and Inwood M.J.H. 1969: Medical Laboratory Technology and Clinical Pathology, London, WB Saunders Company.

Minara M. and Uchiyama M. 1978: Determination of malondialdehyde precursors in tissues by thiobarbituric acid test. Anal. Biochem., 86(1): 271-278.

Mikhailidis D. and WierzBicKi A. 2000: HDL-cholesterol and the treatment of coronary heart disease; contrasting effects of atorvastatin and simvastatin. Curr. Med. Res. Opin., 16(2): 139-146.

Ministry of Health and Family Welfare, Government of India 2001. The ayurvedic pharmacopoeia of India, Annual Report, Government of India, 21-25.

Natelson S. 1951: Routine Use of Ultramicro Methods In The Clinical Laboratory. Am. J. Clin. Pathol. 21: 1153-1172.

Patnaik L. and Patra A.K. 2006: Haemoatopoietic Alterations induced by Carbaryl in Clarias batrachus. J. Applied Sci. Environ. Management, 10(3): 5-7.

Phadke S.A. and KulKarni S.D. 1989: Screening of in vitro antibacterial activity of Eclipta alba. Ind. J. Med. Sci., 43: 113-117.

Prasad A.K., Srivastava S.C., Kumar R. and Srivastava S.P. 1995: Effect of dermal application of hexachlorocyclohexane $(\mathrm{HCH})$ on male reproductive system of rat. Human Exp. Toxicol., 14(6): 484-488.

Rastogi R., Srivastava A.K. and Rastogi A.K. 2001: Long term effect of aflatoxin B(1) on lipid peroxidation in rat liver and kidney: effect of picroliv and silymarin. Phytother. Res., 15: 307-310.

Ronco A.M., Valdés K., Marcus D. and Llanos M. 2001: The mechanism for lindane induced inhibition of steroidogenesis in cultured rat Leydig cells. Toxicol., 159(1-2): 99-106.

Sawane M.V., Kaore S.B., Gaikwad R.D., Patil P.M., Patankar S.S. and Deshkar,A.M. 2002: Seminal LDH-C4 isoenzyme and sperm mitochondrial activity: A study in male partners of infertile couples. Ind. J. Med. Sci., 56(11): 560-561.

Síktar E., Ekinci D., Síktar E., Beydemir S., Gülçın I. and Günay M. 2011: Protective role of L-carnitine supplementation against exhaustive exercise induced oxidative stress in rats. Eur. J. Pharmacol., 668(3): 407-13.

Suwalsky M., Villena F., Marcus D. and Ronco A.M. 2000: Plasma absorption and ultrastructural changes of rat testicular cells induced by lindane. Human Exp. Toxicol. 19(9): 529-533.

Thorat R.M., Jadhav V.M., Gaikwad D.D. and Jadhav S.L. 2010: Phytochemical and pharmacological potential of E. alba. Int. Res. J. Pharm., 1(1): 77-80.

Traina M., Rescia M., Urbani E., Mantovani A., Macri C., Ricciardi C., Stazi A., Fazzi P., Cordelli E., Eleuteri P., Leter G. and Spano M. 2003: Long-lasting effects of lindane on mouse spermatogenesis induced by in utero exposure. Reprod. Toxicol., 17(1): 25-35.

Turkez H. and Geyikoglu F. 2010: Boric acid: a potential chemoprotective agent against aflatoxin b1 toxicity in human blood. Cytotechnol., 62(2): 157-165.

Udoh P.B., Udoh F.V., Umoren E.B., James U.W., Okeke C.P. and Agwu B. 2009: Effect of caricapryl-99 seed alkaloid extract on the serum levels of sex hormones and pituitary gonadotrophins in male albino rats. Niger. J. Physiol. Sci., 24(1): 13-15.

Wagner H., Geyer B., Kiso Y., Hikino H., Rao G.S. 1986: Coumestans as the main active principles of the liver drugs Eclipta alba and Wedelia calendulaceae. Planta Med., 52: 370-374. 
World Health Organization 2010: Laboratory Manual for Examination of Human Semen and Sperm Cervical Mucus Interaction. New York, Cambridge University Press.

Yeung C.H. and Cooper T.G. 1994: Study of the role of epididymal á-glucosidase in the fertility of male rats by the administration of the enzyme inhibitor castanospermine. J. Reprod. Fertil., 102: 401-410.

Zlatkis A., Zak B. and Boyle A.J. 1953: A new method for direct determination of cholesterol. J. Lab. Clin. Med., 41: 486-492.

Electronic articles:

http://www.ilo.org/legacy/english/protection/safework/ghs/.../ghsc11.pdf

Received: 2012-06-22 